\title{
Age-related changes in central corneal thickness in normal eyes among the adult Lithuanian population
}

This article was published in the following Dove Press journal:

Clinical Interventions in Aging

16 July 2014

Number of times this article has been viewed

\author{
Saulius Galgauskas' \\ Grazina Juodkaite' \\ Janina Tutkuviené ${ }^{2}$ \\ 'Center of Eye Diseases, ${ }^{2}$ Faculty of \\ Medicine, Department of Anatomy, \\ Histology and Anthropology, Vilnius \\ University, Vilnius, Lithuania
}

Background: The purpose of this study was to estimate mean central corneal thickness (CCT) and determine whether there are any correlations between CCT, age, and sex in the adult Lithuanian population.

Methods: A total of 1,650 Caucasians of Lithuanian origin (aged 18-89 years) comprising $688(41.7 \%)$ men and 962 (58.3\%) women were examined. Subjects were stratified by age into seven groups. CCT was measured using ultrasonic pachymetry. Correlations between CCT, age, and sex were sought.

Results: Mean ( \pm standard deviation) CCT for both eyes was $544.6 \pm 30.5 \mu \mathrm{m}$. Mean CCT was $545.2 \pm 30.5 \mu \mathrm{m}$ in the left eye and $544.6 \pm 30.5 \mu \mathrm{m}$ in the right eye, and was $545.0 \pm 25.6 \mu \mathrm{m}$ in men and $544.4 \pm 33.5 \mu \mathrm{m}$ in women. Mean CCT was $550.8 \pm 35.7 \mu \mathrm{m}$ in subjects aged $18-29$ years, $557.5 \pm 27.6 \mu \mathrm{m}$ in those aged $30-39$ years, $551.3 \pm 31.4 \mu \mathrm{m}$ in those aged $50-59$ years, $544.0 \pm 31.4 \mu \mathrm{m}$ in those aged $50-59$ years, $544.2 \pm 31.6 \mu \mathrm{m}$ in those aged $60-79$ years, $535.1 \pm 27.8 \mu \mathrm{m}$ in those aged $70-79$ years, and $530.1 \pm 16.8 \mu \mathrm{m}$ in those aged $80-89$ years. No statistically significant difference in CCT was found between the sexes $(P>0.05)$. However, there was a significant difference in subjects aged 18-29 years; men had higher CCT than women $(P<0.05)$. A statistically significant negative correlation was found between CCT and age $(r=-0.263, P<0.05)$ that was stronger in men $(r=-0.406, P<0.05)$ than in women $(r=-0.118, P<0.05)$.

Conclusion: The mean CCT in adult Lithuanians was $544.6 \pm 30.5 \mu \mathrm{m}$, of the left eye $545.2 \pm 30.5 \mu \mathrm{m}$ and of the right $-544.6 \pm 30.5 \mu \mathrm{m}$. CCT of the right eye was equal to the CCT of both eyes. Mean CCT was $545.0 \pm 25.6 \mu \mathrm{m}$ in men and $544.4 \pm 33.5 \mu \mathrm{m}$ in women. Young men tended to have higher CCT than women. CCT decreases over the lifetime, meaning that older people have thinner corneas. CCT's dependence on age is stronger in men.

Keywords: central corneal thickness, age, gender, percentile

\section{Introduction}

The cornea is part of the optical system of the eye, and its condition is directly related to the quality of eyesight. Measurement of central corneal thickness (CCT) and endothelial cell parameters is important when undertaking a functional and morphologic evaluation of the cornea for diagnostic purposes or before various surgical interventions.

Due to the increasing popularity of correction of refractive defects by excimer laser, CCT has come to have higher prognostic significance for determination of the success of surgery and probable post-surgical complications. CCT is always measured before such procedures. Surgery in the case of a cornea that is too thin may result in a very serious postoperative complication, ie, corneal ectasia. It has been assumed that the optimal CCT for refractive surgery is more than $500 \mu \mathrm{m}$; however, opinions regarding the impact of CCT in anticipating treatment of refractive defects (ie, which CCT
Correspondence: Saulius Galgauskas Vilnius University Faculty of Medicine, Vilnius University Hospital Santariskiu Clinic, Center of Eye Diseases, Santariskiu 2,Vilnius 0866I, Lithuania $\mathrm{Tel}+37068726238$

Email saulius.galgauskas@santa.It 
value is too low to perform surgery safely) are not consistent and studies of patients with relatively thin CCT indicate no excess risk for postoperative complications. ${ }^{1,2}$

It should be remembered that intraocular pressure depends on corneal thickness; a thick cornea may explain a falsely elevated intraocular pressure reading and, conversely, falsely low intraocular pressure is measured in eyes with thin corneas. ${ }^{3-5}$ This should be taken into consideration in order to avoid both overdiagnosis and underdiagnosis of glaucoma and ocular hypertension. Factors thought to affect CCT include race, age, sex, anthropometric parameters, drugs, time of day, blink rate, and type of measuring equipment used. It has also been established that CCT varies according to ethnicity. However, none of these factors alone is able to predict CCT.

Standards must be established in order to compare results obtained in different population groups. Since CCT varies in these populations, it is very important to verify the results and determine the limits of normal values. ${ }^{6-8}$ Further, corneal parameters differ according to patient age. ${ }^{6-13}$ Awareness of these ethnicity-related and age-related physiologic changes enables us to assess the influence of disease and surgical procedures more accurately. The purpose of this study was to estimate the mean CCT in the Lithuanian population and compare CCT between subjects according to age group and identify correlations between CCT, age, and sex.

\section{Materials and methods}

This was a prospective study performed between March 2009 and December 2010, and enrolled Lithuanian citizens visiting primary health care institutions in the cities and regions of Vilnius, Kaunas, Klaipėda, Šiauliai, Panevėžys, Telšiai, Tauragè, Utena, Alytus, and Marijampolè. All measurements were taken by the same examiner, who visited the abovementioned health care institutions during the study period.

After obtaining informed consent, 1,650 adult Caucasians comprising 688 (41.7\%) men and 962 (58.3\%) women of Lithuanian origin were examined. Participants had a standardized interview about any previous or current ocular disease, previous eye trauma or surgery, wearing of contact lenses, and comorbidity, eg, diabetes or other chronic disease that may influence CCT. CCT was measured using an ultrasound contact pachymeter (Quantel Medical, France), applying one drop of $0.5 \%$ proxymetacaine (Alcon-Couvreur, Puurs, Belgium) for local anesthesia. The pachymeter automatically recorded five CCT measurements and the mean value was taken as the result of the test. Participants were seated during the examination.

Subject age and sex were recorded. Exclusion criteria were history of corneal degeneration or ulceration, anterior
Table I Distribution of subjects by age and sex

\begin{tabular}{|c|c|c|c|c|c|c|}
\hline \multirow[t]{3}{*}{ Age (years) } & \multicolumn{6}{|l|}{ sex } \\
\hline & \multicolumn{2}{|l|}{ Male } & \multicolumn{2}{|c|}{ Female } & \multicolumn{2}{|l|}{ Total } \\
\hline & $\%$ & $\mathbf{n}$ & $\%$ & $\mathbf{n}$ & $\%$ & $\mathbf{n}$ \\
\hline $18-29$ & $8.0 \%$ & 56 & $11.3 \%$ & 110 & $10.0 \%$ & 166 \\
\hline $30-39$ & $14.4 \%$ & 99 & $10.8 \%$ & 104 & $12.3 \%$ & 203 \\
\hline $40-49$ & $14.4 \%$ & 99 & $22.7 \%$ & 218 & $19.2 \%$ & 317 \\
\hline $50-59$ & $15.7 \%$ & 108 & $18.3 \%$ & 176 & $17.2 \%$ & 284 \\
\hline $60-69$ & $14.7 \%$ & 101 & $13.5 \%$ & 130 & $14.0 \%$ & 231 \\
\hline 70-79 & $15.6 \%$ & 107 & $11.3 \%$ & 108 & $13.1 \%$ & 215 \\
\hline 80-89 & $17.2 \%$ & 118 & $12.1 \%$ & 116 & $14.2 \%$ & 234 \\
\hline In total & $100.0 \%$ & 688 & $100.0 \%$ & 962 & $100.0 \%$ & 1.650 \\
\hline
\end{tabular}

segment surgical procedures, glaucoma, diabetes mellitus, current conjunctivitis, or wearing of contact lenses. Subject age ranged from 18 to 89 years. The subjects were stratified into seven groups on the basis of age as follows: 18-29 years, 30-39 years, 40-49 years, 50-59 years, 60-69 years, 70-79 years, and 80-89 years (Table 1). The sex distribution of the participants was similar; however, there were more women in the age groups of 18-29, 40-49, 50-59, and 60-69 years. Mean CCT was calculated and the results were compared between the groups. Correlations between CCT, age, and sex were found. The study protocol followed the guidelines of the Declaration of Helsinki and was approved by the local ethics committee.

\section{Statistical analysis}

Statistical Package for the Social Sciences version 17.0 software (SPSS Inc., Chicago, IL, USA) was used for the statistical analysis. Continuous variables were evaluated using the mean and standard deviation. When the distribution was normal, the mean differences between independent samples for the two groups were assessed using the Student's twosided $t$-test, and the paired Student's $t$-test was used to compare means of dependent samples. Means of more than two groups were compared using one-way analysis of variance. A $P$-value less than 0.05 was considered to be statistically significant. The Pearson correlation coefficient was used to establish correlations.

\section{Results}

The average age of the study population was $55.4 \pm 19.2$ years (53.6 \pm 18.8 years for women and $57.3 \pm 19.5$ years for men). Mean CCT for the overall patient population was $544.6 \pm 30.5$ (range 654-449) $\mu \mathrm{m}$ in the right eye (Figure 1), $545.2 \pm 30.5$ (range 650-451) $\mu \mathrm{m}$ in the left eye (Figure 2), and $544.6 \pm 30.5 \mu \mathrm{m}$ in both eyes. The average CCT for both eyes was $545.0 \pm 26.4 \mu \mathrm{m}$ in men and $544.4 \pm 33.2 \mu \mathrm{m}$ in women. There was no statistically significant difference 


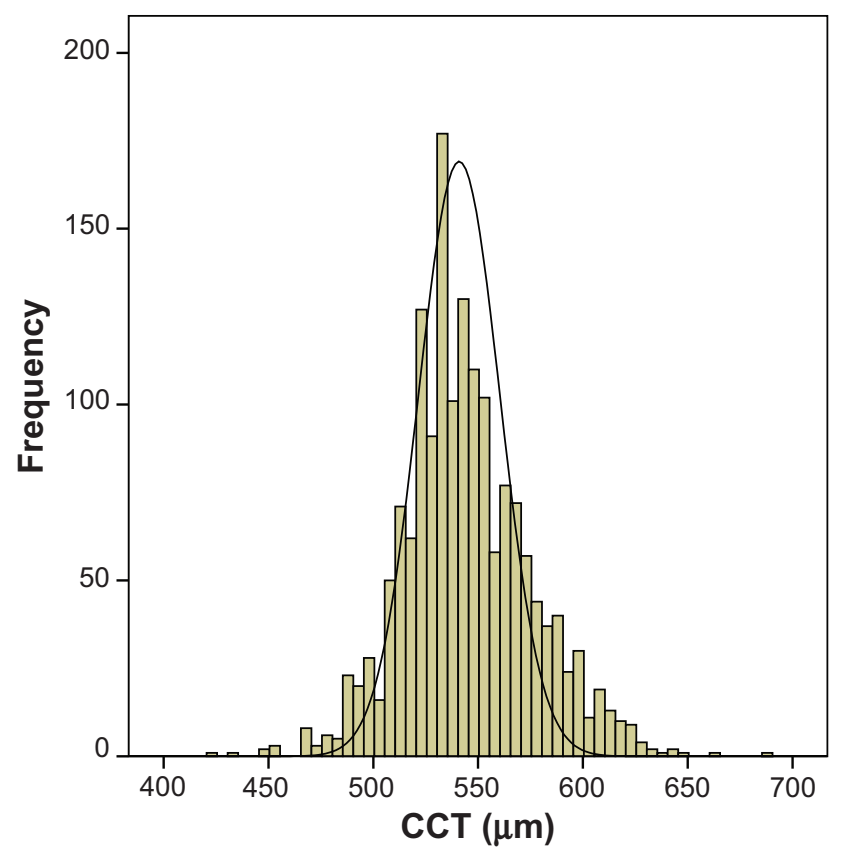

Figure I Histogram of CCT $(\mu \mathrm{m})$ in the right eye.

Abbreviation: CCT, central corneal thickness.

in CCT between the eyes $(P>0.05)$, so the right eye was selected for further investigation. The average CCT for the right eye in men was $545.0 \pm 25.6$ (range 468-645) $\mu \mathrm{m}$ and for women was $544.4 \pm 33.5$ (range $449-654$ ) $\mu \mathrm{m}$. No statistically significant difference was found between the sexes $(P>0.05)$; however, there was a significant sex difference in one age group, ie, men aged 18-29 years had higher CCT than women $(P<0.05)$. The average $\mathrm{CCT}(\mu \mathrm{m})$ according to age group is shown in Table 2 .

A statistically significant weak negative correlation was found between CCT and age $(r=-0.263, P<0.05)$. This relationship was stronger in men (a moderate negative correlation; $r=-0.406, P<0.05$ ) than in women (a weak negative correlation; $r=-0.118, P<0.05$ ). Taken overall, CCT decreases over the lifetime in both sexes (Figures 3-5), but the age-dependence of CCT is stronger in men. Percentiles were calculated for CCT according

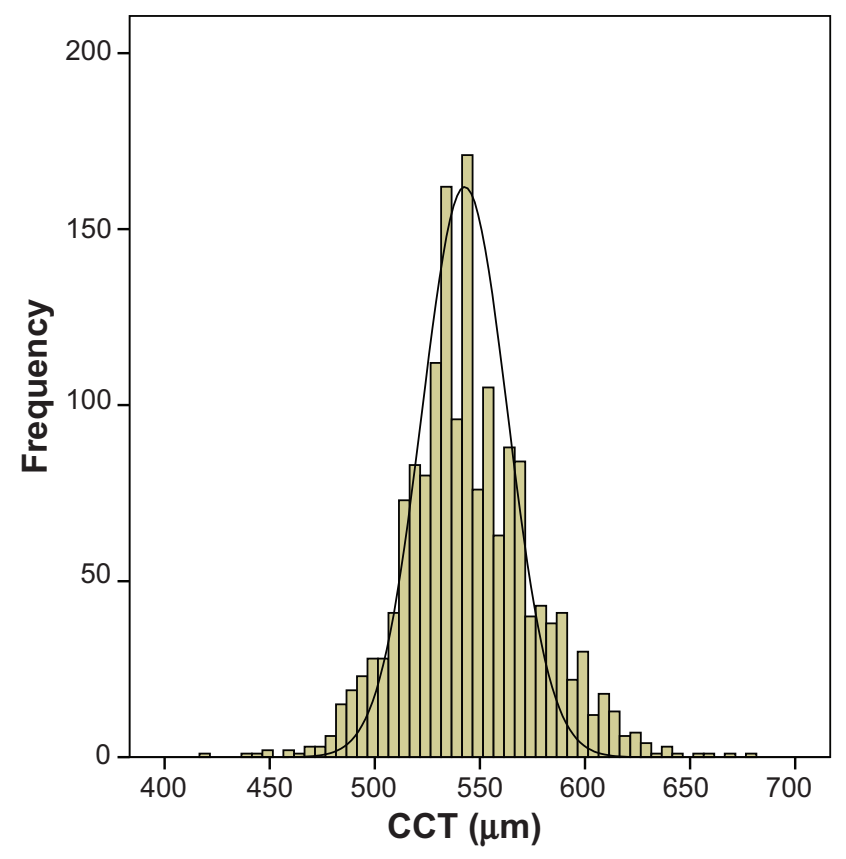

Figure 2 Histogram of CCT $(\mu \mathrm{m})$ in the left eye. Abbreviation: CCT, central corneal thickness.

to subject age group ( $<40$ years, $40-60$ years, and $>60$ years, see Table 3 ). Corneas were thinner in people over 60 years of age when compared with the other age groups $(P<0.05)$.

Mean CCT values were classified into percentiles as follows: $<489 \mu \mathrm{m}$ (percentile $<3$, extremely thin cornea); 489$510 \mu \mathrm{m}$ (percentile 3-10, moderately thin cornea); 510$524 \mu \mathrm{m}$ (percentile 10-25, mildly thin cornea); 524-564 $\mu \mathrm{m}$ (percentile 25-75, average corneal thickness); 564-586 $\mu \mathrm{m}$ (percentile 75-90, mildly thick cornea); 586-609 $\mu \mathrm{m}$ (percentile 90-97, moderately thick cornea); and $>609 \mu \mathrm{m}$ (percentile $>97$, extremely thick cornea). More details on percentiles for CCT are shown in Table 3.

\section{Discussion}

The purpose of this study was to estimate mean CCT in adult Lithuanians and identify any correlations between

Table 2 Mean central corneal thickness $(\mu \mathrm{m})$ in each age group

\begin{tabular}{|c|c|c|c|c|c|c|c|c|c|c|c|c|}
\hline \multirow[t]{2}{*}{ Age, years } & \multicolumn{4}{|l|}{ Men } & \multicolumn{4}{|c|}{ Women } & \multicolumn{4}{|l|}{ Total } \\
\hline & Mean & Minimum & Maximum & SD & Mean & Minimum & Maximum & SD & Mean & Minimum & Maximum & SD \\
\hline $18-29$ & 559.4 & 492 & 626 & 33.9 & 546.5 & 451 & 629 & 35.9 & 550.8 & 451 & 629 & 35.7 \\
\hline $30-39$ & 560.3 & 506 & 645 & 24.3 & 554.8 & 470 & 628 & 30.3 & 557.5 & 470 & 645 & 27.6 \\
\hline $40-49$ & 553.5 & 493 & 625 & 25.0 & 550.3 & 449 & 654 & 33.9 & 551.3 & 449 & 654 & 31.4 \\
\hline 50-59 & 544.8 & 468 & 603 & 25.7 & 543.4 & 466 & 650 & 34.5 & 544.0 & 466 & 650 & 31.4 \\
\hline $60-69$ & 541.2 & 479 & 607 & 24.8 & 546.5 & 467 & 654 & 35.9 & 544.2 & 467 & 654 & 31.6 \\
\hline 70-79 & 534.7 & 490 & 623 & 19.4 & 535.5 & 449 & 616 & 34.3 & 535.1 & 449 & 623 & 27.8 \\
\hline $80+$ & 530.9 & 490 & 566 & 15.2 & 529.2 & 475 & 599 & 18.3 & 530.1 & 475 & 599 & 16.8 \\
\hline
\end{tabular}

Abbreviation: SD, standard deviation. 


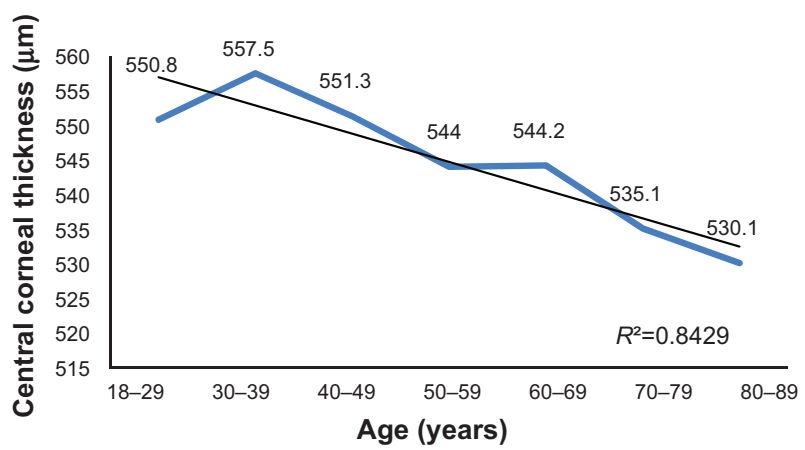

Figure 3 Change in central corneal thickness across age groups.

CCT, age, and sex. Studies have investigated mean values for CCT among different populations throughout the world. There are reasonable data showing differences in CCT between various ethnic groups. ${ }^{14,15}$ The mean CCT in our study $(544.6 \mu \mathrm{m})$ was similar to that of $545.2 \mu \mathrm{m}$ reported for the Caucasian population by Nemesure et al and within the limits for mean CCT reported by other studies, ie, 520-579 $\mu \mathrm{m} .{ }^{6,16-18}$ The corneas of African Americans have been reported to be thinner and those of Caucasians and Mongoloids as thicker. ${ }^{6,9,14,15,19-23}$ Thin corneas were identified in Mongoloids residing in Mongolia (504.5 $\mu \mathrm{m})$ and India $(520.7 \mu \mathrm{m})$, whereas Mongoloids living in Singapore and the People's Republic of China had CCT values similar to those of Caucasians $(541.2 \mu \mathrm{m}$ and $556.2 \mu \mathrm{m}$, respectively). ${ }^{9,14,15,19}$

Some of the available data show that CCT correlates significantly with sex while others do not. We found no statistically significant difference between sex and CCT $(P>0.05)$. However, a statistically significant difference was found between young men and women aged 18-29 years, with CCT being higher in men. Leskul et al did not find any correlation between these parameters in their study in Thailand, in which 467 subjects aged $12-60$ years were examined. ${ }^{24}$ Hashemi et al examined 800 eyes and also did not find any relationship between CCT and sex. ${ }^{25}$ Eballe et al examined 970 eyes in

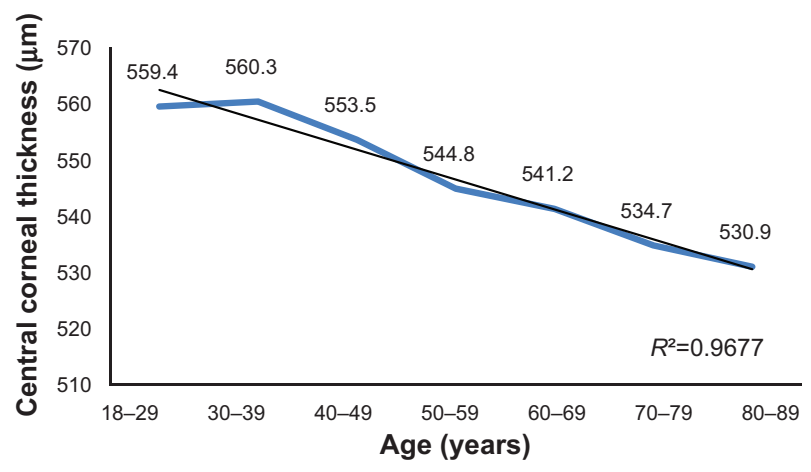

Figure 4 Change in central corneal thickness across age groups in men.

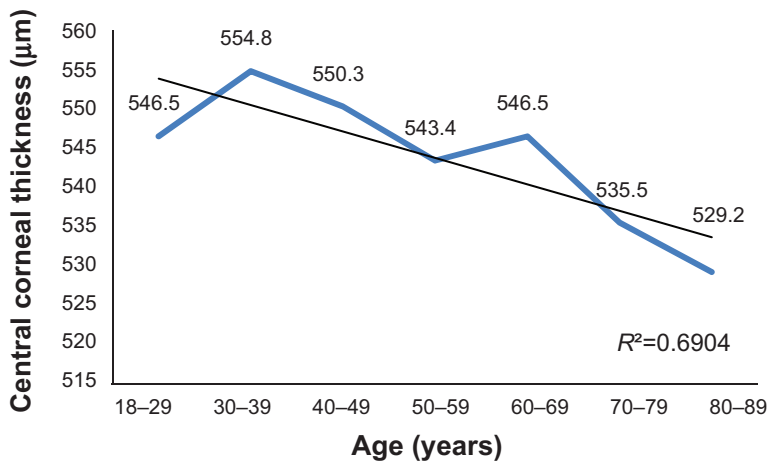

Figure 5 Change in central corneal thickness across age groups in women.

their study and reported finding no statistically significant difference in CCT between men and women. ${ }^{8}$ Findings of other studies indicate that corneas are thicker in men than in women. In the Beijing Eye Study conducted in 2008 in the People's Republic of China, Xu et al examined 3,251 participants and found that corneas were thicker in men than in women. ${ }^{26}$ Suzuki et al examined 2,848 men and 4,465 women and came to the same conclusion (finding a mean CCT of $521 \mu \mathrm{m}$ in men and $514 \mu \mathrm{m}$ in women). ${ }^{27}$ Similar results have been published elsewhere. ${ }^{28-30}$

There is no clear answer as to why women have thinner corneas than men. It is possible that hormonal changes in women may account for this difference. It has been shown established that CCT is lowest in women at the beginning of the menstrual cycle and highest at the end and during ovulation. ${ }^{31}$ Further, Keskin et al determined that CCT was significantly decreased in postmenopausal women compared with their premenopausal counterparts. ${ }^{32}$

We observed a weak correlation between CCT and age. However, opinions as to the relevance of these two factors are mixed. Some authors did not define any dependence between these parameters; others, however, refer to a decrease in CCT with age. ${ }^{7,933}$ Kamiya et al examined 204 eyes from 204 healthy subjects, and reported that biomechanical data for the cornea change during the course of the lifetime, but could not identify significant changes in age-related CCT or intraocular pressure. ${ }^{34}$ Mercieca et al reported that the cornea becomes thinner with age and mean CCT is lower in women than in men. ${ }^{10}$ The Reikjavik Eye study published in 2002, in which 925 healthy people aged 50 years and older were examined, showed that CCT does not depend on age. ${ }^{4}$ Prasad et al reached the same conclusion after measuring corneal parameters in 5,158 subjects. ${ }^{35}$

Thinning of the cornea at a rate of 3-7 $\mu \mathrm{m}$ per decade has been observed in older age in some ethnic groups. A study in 1998 with 1,242 participants aged 10-87 years showed that 
Table 3 Percentiles of central corneal thickness $(\mu \mathrm{m})$

\begin{tabular}{|c|c|c|c|c|c|c|c|}
\hline & & Men and women & Men & Women & $<\mathbf{4 0}$ years & $40-60$ years & $60+$ years \\
\hline \multirow{9}{*}{ 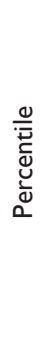 } & 3 & 489 & 500 & 486 & 493 & 489 & 489 \\
\hline & 5 & 499 & 508 & 493 & 506 & 499 & 495 \\
\hline & 10 & 510 & 514 & 506 & 516 & 510 & 508 \\
\hline & 25 & 524 & 528 & 523 & 535 & 528 & 522 \\
\hline & 50 & 542 & 544 & 541 & 553 & 545 & 533 \\
\hline & 75 & 564 & 562 & 565 & 574 & 569 & 548 \\
\hline & 90 & 586 & 580 & 590 & 599 & 589 & 566 \\
\hline & 95 & 599 & 590 & 604 & 611 & 600 & 586 \\
\hline & 97 & 609 & 601 & 612 & 618 & 609 & 596 \\
\hline
\end{tabular}

CCT decreased by 5- $6 \mu \mathrm{m}$ for each decade of life. ${ }^{9}$ Eballe et al reported that CCT decreases by $4.2 \mu \mathrm{m}$ for each 10 years of life, with the thickest corneas found in subjects younger than 20 years. ${ }^{8}$ Aghaian et al indicated that CCT decreased by $3 \mu \mathrm{m}$ over a decade, and Brandt et al reported a $6.3 \mu \mathrm{m}$ decrease over the same period. ${ }^{14,36}$ Our data show that CCT is decreasing at a rate of $2-8 \mu \mathrm{m}$ per decade in Lithuanians over 40 years of age. Leskul et al examined 467 subjects aged 12-60 years of age and found that young people had higher CCT. ${ }^{24} \mathrm{~A}$ similar conclusion was reached in the Liwan Eye Study reported by Wang et al. ${ }^{11}$ Wangsupadilok et al also identified corneal thinning over the lifetime after examining subjects aged $18-96$ years. ${ }^{37}$ Pfeiffer et al, who reported the European Glaucoma Prevention Study, found that younger persons had thicker corneas. ${ }^{12}$ Narayanaswamy et al who examined 1,132 individuals, reported that biomechanical features of the cornea change with the age, ie, there is a reduction in corneal resistance factor and corneal hysteresis. ${ }^{13}$

The impact of age on corneal thickness can explained in a number of different ways. Referring to theory based on histologic studies, the corneas of older people are thinner because of a reduction in keratocyte density and possible destruction of collagen fibers, and senior individuals are exposed to environmental factors for a longer period of time, which might influence corneal structure. ${ }^{38}$ Hasemian et al demonstrated that corneal endothelial cell density decreases in persons until 60 years of age; however, the volume of these cells increases. ${ }^{39}$ As yet there is no consensus among scientists as to whether the corneal endothelium and CCT are interdependent. ${ }^{40,41}$

It has been established that CCT is lower in children of African American origin (same as in adults) in comparison with Caucasian children. ${ }^{42,43}$ It has also been demonstrated that CCT is lower in children born prematurely than in those born at term. ${ }^{42,44}$ Lim et al examined 271 children of various ages and did not found any interdependence between CCT and the axial length of the eye or refractive defects. ${ }^{45}$ Hikoya et al examined 169 children aged $1-18$ years and established that CCT in Japanese children is lower than in Caucasian children, but higher than in children of African American origin. ${ }^{46}$ Osmera et al who examined 124 subjects from 7 to 17 years of age, reported that CCT and intraocular pressure values in Czech children and adults are very similar to those in adults. ${ }^{47} \mathrm{In}$ a study involving 106 children younger than 18 years, Dai et al determined that corneas in children of African American origin were thinner than in Caucasians. ${ }^{48}$ Further, a survey conducted in Singapore showed that Chinese children had thicker corneas than Malay or Indian children. ${ }^{49}$

Classification of CCT according to our nomogram could be used in clinical practice to evaluate a patient's CCT in context of the rest of the population, ie, percentile $<3$, severely thin cornea; percentile 3-10, moderately thin; percentile 10-25, mildly thin; percentile $25-75$ average thickness; percentile 75-90, mildly thick; percentile 90-97, moderately thick; and percentile $>97$, severely thick cornea.

\section{Conclusion}

Our study shows that the mean CCT of the adult Lithuanian population is similar to the corneal thicknesses reported for other Caucasian populations, and was within the limits of the mean CCT defined in similar studies. A difference in CCT between the sexes was observed only in the youngest age group, indicating that young men have a higher CCT than women. A weak negative relationship between $\mathrm{CCT}$ and age was observed, indicating that older people have thinner corneas. This age dependence was stronger in men (a moderate negative correlation) than in women (a weak negative correlation). A nomogram for CCT in the Lithuanian population was compiled based on this study. These data will help to evaluate CCT in our patients in a more practical and accurate manner.

\section{Disclosure}

The authors report no conflicts of interest in this work. 


\section{References}

1. Caster AI, Friess DW, Potvin RJ. Absence of keratectasia after LASIK in eyes with preoperative central corneal thickness of 450 to 500 microns. J Refract Surg. 2007;23(8):782-788.

2. Binder PS. Analysis of ectasia after laser in situ keratomileusis: risk factors. J Cataract Refract Surg. 2007;33(9):1530-1538.

3. Galgauskas S, Ringailaite E, Juodkaite G. [Central corneal thickness and its relationship to gender, intraocular pressure and corneal curvature]. Medicinos Teorija ir Praktika. 2009;15(1):19-23. Lithuanian.

4. Eysteinsson T, Jonasson F, Sasaki H, et al. Central corneal thickness, radius of the corneal curvature and intraocular pressure in normal subjects using non-contact, techniques: Reykjavik Eye Study. Acta Ophthalmol Scand. 2002;80(1):11-15.

5. Leskul M, Aimpun P, Nawanopparatskul B, et al. The correlations between central corneal thickness and age, gender, intraocular pressure and refractive error of aged 12-60. J Med Assoc Thai. 2005;88 Suppl 3: S175-S179.

6. Nemesure B, Wu SY, Hennis A, Leske C. Corneal thickness and intraocular pressure in the Barbados eye studies. Arch Ophthalmol. 2003;121(2):240-244.

7. Hahn S, Azen S, Ying-Lai M, Varma R; Los Angeles Latino Eye Study Group. Central corneal thickness in Latinos. Invest Ophthalmol Vis Sci. 2003;44(4):1508-1512.

8. Eballe AO, Koki G, Ellong A, Owono D, Epee E, Bella LA. Central corneal thickness and intraocular pressure in the Cameroonian non glaucomatous population. Clin Ophthalmol. 2010;4:717-724.

9. Foster PJ, Baasanhu J, Alsbirk PH, Munkhbayar D, Uranchimeg D, Johnson GJ. Central corneal thickness and intraocular pressure in a Mongolian population. Ophthalmology. 1998;105(6):969-973.

10. Mercieca K, Odogu V, Fiebai B, Arowolo O, Chukwuka F. Comparing central corneal thickness in a sub-Saharan cohort to African Americans and Afro-Caribbeans. Cornea. 2007;26(5):557-560.

11. Wang D, Huang W, Li Y, et al. Intraocular pressure, central corneal thickness, and glaucoma in Chinese adults: the Liwan Eye Study. Am J Ophthalmology. 2011;152(3):454-462.

12. Pfeiffer N, Torri V, Miglior S, Zeyen T, Adamsons I, Cunha-Vaz J. Central corneal thickness in the European Glaucoma Prevention Study. Ophthalmology. 2007;114(3):454-459.

13. Narayanaswamy A, Chung RS, Wu RY, et al. Determinations of corneal biomechanical properties in an adult Chinese population. Ophthalmology. 2011;118(7):1253-1259.

14. Aghaian E, Choe JE, Lin S, Stamper RL. Central corneal thickness of Caucasians, Chinese, Hispanics, Filipinos, African Americans, and Japanese in a glaucoma clinic. Ophthalmology. 2004;111(12): 211-2219.

15. La Rosa FA, Gross RL, Orengo-Nania S. Central corneal thickness of Caucasians and African Americans in glaucomatous and non glaucomatous populations. Arch Ophthalmol. 2001;119(1):23-27.

16. Cankaya AB, Elgin U, Batman A, Acaroglu G. Relationship between central corneal thickness and parameters of optic nerve head topography in healthy subjects. Eur J Ophthalmol. 2008;18(1):32-38.

17. Casson RJ, Abraham LM, Newland HS, et al. Corneal thickness and intraocular pressure in a nonglaucomatous Burmese population: the Meiktila Eye Study. Arch Ophthalmol. 2008;126(7):981-985.

18. Mello PR, Meirelles SH, Moraes Junior HV. [Correlation between central corneal thickness and axial length in patient with glaucoma and normal eye]. Arq Bras Oftalmol. 2009;72(4):497-502. Portuguese.

19. Lee ES, Kim CY, Ha SJ, Seong GJ, Hong YJ. Central corneal thickness of Korean patients with glaucoma. Ophthalmology. 2007;114(5): 927-930.

20. Miglior S, Pfeiffer N, Torri V, Zeyen T, Cunha-Vaz J, Adamsons I. Predictive factors for open-angle glaucoma among patients with ocular hypertension in the European Glaucoma Prevention Study. Ophthalmology. 2007;114(1):3-9.

21. Shimmyo M. Intraocular pressure, Goldmann applanation tension, corneal thickness, and corneal curvature in Caucasians, Asians, Hispanics, and African Americans. Am J Ophthalmol. 2004;137(6):1170.
22. Torres RJ, Jones E, Edmunds B, Becker T, Cioffi GA, Mansberger SL. Central corneal thickness in North western American Indians/Alaskan Natives and comparison with white and African-American persons. Am J Ophthalmol. 2008;146(5):747-751.

23. Zhao MH, Zou J, Wang WQ, Li J. Comparison of central corneal thickness as measured by non-contact specular microscopy and ultrasound pachymetry before and post LASIK. Clin Experiment Ophthalmol. 2007;35(9):818-823.

24. Leskul M, Aimpun P, Nawanopparatskul B, et al. The correlations between central corneal thickness and age, gender, intraocular pressure and refractive error of aged 12-60. J Med Assoc Thai. 2005;88 Suppl 3: S175-S179.

25. Hashemi H, Yazdani K, Mehravaran S, KhabazKhoob M, Mohammad K, Parsafar $\mathrm{H}$, et al. Corneal thickness in a population based, cross sectional study: the Tehran Eye Study. Cornea. 2009;28:395-340.

26. Xu L, Zhang H, Wang YX, Jonas JB. Central corneal thickness and glaucoma in adult Chinese: the Beijing Eye Study. $J$ Glaucoma. 2008;17(8):647-653.

27. Suzuki S, Suzuki Y, Iwase A, Araie M. Corneal thickness in an ophthalmologically normal Japanese population. Ophthalmology. 2005;112(8): 1327-1336.

28. Nomura H, Ando F, Niino N, Shimokata H, Miyake Y. The relationship between age and intraocular pressure in a Japanese population: the influence of central corneal thickness. Curr Eye Res. 2002;24(2): $81-85$.

29. Garcia-Medina M, Garsia-Medina JJ, Garrid-Fernandez P, et al. Central corneal thickness, intraocular pressure, and degree of myopia in an adult myopic population aged 20 to 40 in southeast Spain: determination and relationships. Clin Ophthalmol. 2011;5:249-258.

30. Vijaya L, George R, Baskaran M, et al. Prevalence of primary openangle glaucoma in an urban south Indian population and comparison with a rural population. The Chennai Glaucoma Study. Ophthalmology. 2008;115(4):648-654.

31. Goldich Y, Barkana Y, Pras E, et al. Variations in corneal biomechanical parameters and central corneal thickness during the menstrual cycle. J Cataract Refract Surg. 2011;37(8):1507-1511.

32. Keskin N, Canturk S, Aydin S, Saygili H, Ozgün C. An objective method to determine corneal changes during menopause. Clin Exp Obstet Gynecol. 2009;36(3):176-178.

33. Tomidokoro A, Araie M, Iwase A. Corneal thickness and relating factors in a population-based study in Japan: the Tajimi Study. Am J Ophthalmol. 2007;144(1):152-154.

34. Kamiya K, Shimizu K, Ohmoto F. Effect of aging on corneal biomechanical parameters using the ocular response analyzer. J Refract Surg. 2009;25(10):888-893.

35. Prasad A, Fry K, Hersh PS. Relationship of age and refraction to central corneal thickness. Cornea. 2011;30(5):553-555.

36. Brandt JD, Beiser JA, Kass MA, Gordon MO. Central corneal thickness in the Ocular Hypertension Treatment Study (OHTS). Ophthalmology. 2001;108(10):1779-1788.

37. Wangsupadilok B, Horatanaruang O. The impact of central corneal thickness on intraocular pressure measured by noncontact tonometry. J Med Assoc Thai. 2011;94(5):574-578.

38. Patel HY, Patel DV, McGhee CN. Identifying relationships between tomography-derived corneal thickness, curvature, and diameter and in vivo confocal microscopic assessment of the endothelium in healthy corneas of young adults. Eye. 2009;23(2):270-278.

39. Hashemian MN, Moghimi S, Fard MA, Fallah MR, Mansouri MR. Corneal endothelial cell density and morphology in normal Iranian eyes. BMC Ophthalmol. 2006;6:9-10.

40. Korey M, Gieser D, Kass MD, Waltman SR, Gordon M, Becker B. Central corneal endothelial cell density and central corneal thickness in ocular hypertension and primary open-angle glaucoma. Am J Ophthalmol. 1982;94(5):610-616.

41. Modis L Jr, Langenbucher A, Seitz B. Corneal thickness measurements with contact and noncontact specular microscopic and ultrasonic pachymetry. Am J Ophthalmol. 2001;132(4):517-521. 
42. Haider KM, Mickler C, Oliver D, Moya FJ, Cruz OA, Davitt BV. Age and racial variation in central corneal thickness of preschool and school aged children. J Pediatr Ophthalmol Strabismus. 2008;45(4): 227-323.

43. Muir KW, Duncan L, Enyedi LB, Freedman SF. Central corneal thickness in children. Racial differences (black vs white) and correlation with measured intraocular pressure. J Glaucoma. 2006;15(6):520-523.

44. Kirwan C, O'Keefe M, Fitzsimon S. Central corneal thickness and corneal diameter in premature infants. Acta Ophthalmol Scand. 2005;83(6): 751-753.

45. Lim L, Gazzaid G, Chan YH, et al. Cornea biomechanical characteristics and their correlates with refractive error in Singaporean children. Invest Ophthalmol Vis Sci. 2008;49(9):3852-3857.

46. Hikoya A, Sato M, Tsuzuki K, Koide YM, Asaoka R, Hotta Y. Central corneal thickness in Japanese children. Jpn J Ophthalmol. 2009;53(1): 7-11.
47. Osmera J, Filous A, Hlozanek M. [Central corneal thickness, intraocular pressure and their correlation in healthy Czech children aged 7-17 years]. Cesk Slov Oftalmol. 2009;65(1):19-23. Czech.

48. Dai E, Gunderson CA. Pediatric central corneal thickness variation among major ethnic populations. J AAPOS. 2006;10(1):22-25.

49. Tong L, Saw SM, Siak JK, Gazzard G, Tan D. Corneal thickness determination and correlates in Singaporean schoolchildren. Invest Ophthalmol Vis Sci. 2004;45(11):4004-4009.
Clinical Interventions in Aging

\section{Publish your work in this journal}

Clinical Interventions in Aging is an international, peer-reviewed journal focusing on evidence-based reports on the value or lack thereof of treatments intended to prevent or delay the onset of maladaptive correlates of aging in human beings. This journal is indexed on PubMed Central, MedLine,
Dovepress

CAS, Scopus and the Elsevier Bibliographic databases. The manuscript management system is completely online and includes a very quick and fair peer-review system, which is all easy to use. Visit http://www.dovepress. com/testimonials.php to read real quotes from published authors. 